\title{
Magnetic resonance imaging and ultrasound in hepatosplenic schistosomiasis mansoni
}

\author{
Ressonância magnética e ultrassonografia na \\ esquistossomose mansoni hepatoesplênica
}

\author{
José Roberto Lambertucci ${ }^{1}$, Luciana Cristina dos Santos Silva ${ }^{1}$, Luciene Mota Andrade ${ }^{2}$, \\ Leonardo Campos de Queiroz ${ }^{3}$ and Rogério Augusto Pinto-Silva ${ }^{3}$
}

\begin{abstract}
We report the findings of abdominal ultrasound and magnetic resonance imaging observed in a patient with advanced schistosomiasis mansoni. A 25-year-old man with hepatosplenic schistosomiasis and variceal bleeding confirmed by upper endoscopy was submitted to abdominal ultrasound and magnetic resonance imaging. During surgery for portal hypertension, a liver biopsy was taken and the diagnosis of Symmers' fibrosis was confirmed. Magnetic resonance imaging scans gave more precise information about the gallbladder, periportal thickening and abdominal venous system than did the ultrasound.
\end{abstract}

Key-words: Hepatosplenic schistosomiasis mansoni. Ultrasound. Magnetic resonance imaging.

\section{RESUM0}

Relatamos os achados ultrassonográficos e à ressonância magnética intra-abdominais observados em um paciente com esquistossomose mansoni grave. Um homem de 25 anos de idade com esquistossomose hepatoesplênica e sangramento digestivo de varizes esofagianas, com diagnóstico confirmado pela endoscopia, foi submetido à ultrasonografia abdominal e ressonância magnética. Durante a cirurgia de hipertensão porta, um fragmento de fígado foi obtido e 0 exame histológico confirmou o diagnóstico de fibrose de Symmers. A ressonância magnética forneceu informações mais precisas sobre a vesícula biliar, espessamento periportal e sistema venoso abdominal do que a ultrassonografia.

Palavras-chaves: Esquistossomose mansoni hepatoesplênica. Ultrassonografia. Ressonância magnética.

Diagnosis of hepatosplenic schistosomiasis and stratification of morbidity permit identification of cases with higher risk of complications such as, variceal bleeding, pulmonary hypertension, and glomerulonephritis, thereby allowing a more rational approach to treatment ${ }^{151920}$. Abdominal ultrasonography (US) is an indirect method of diagnosis of schistosomiasis, and represents a tool in the classification of the clinical forms of the disease ${ }^{4516}{ }^{18}$. However, there still is little information about the correlation of US findings and the various aspects of morbidity in schistosomiasis ${ }^{18}$.
Magnetic resonance imaging (MRI) has been shown to be a sensitive imaging technique in the evaluation of a variety of diseases. Unlike US, it is not a dynamic examination and can be less vulnerable to intra and inter-examiner variability ${ }^{12}$. Some findings of MRI, with different equipment, have been reported previously in three cases of hepatosplenic schistosomiasis mansoni ${ }^{81421}$, with promising results. We report here in a man with severe hepatosplenic schistosomiasis the evaluation by ultrasonography and magnetic resonance imaging of the abdomen.

1. Serviço de Doenças Infecciosas e Parasitárias da Faculdade de Medicina da Universidade Federal de Minas Gerais, Belo Horizonte, MG. 2. Laboratórios Hermes Pardini, Belo Horizonte, MG. 3. Serviço de Radiologia do Hospital das Clínicas da Universidade Federal de Minas Gerais, Belo Horizonte, MG.

Address to: Dr. José Roberto Lambertucci. Serviço de Doenças Infecciosas e Parasitárias/FM/UFMG. Av. Alfredo Balena 190, Santa Efigênia, 30130-100 Belo Horizonte, MG, Brasil,

Tel: 5531 3248-9821

E-mail: lamber@net.em.com.br

Recebido para publicação em 26/3/2004

Aceito em 5/5/2004 


\section{PATIENT AND METHODS}

A 25-year-old man was referred to the Hospital of the Federal University of Minas Gerais, in Brazil, for evaluation of anemia which did not respond to medical treatment. He was born and resided in an area endemic for schistosomiasis. Eleven years before admission, stool examination disclosed viable eggs of Schistosoma mansoni. He received praziquantel, but maintained frequent contact with stream water. He reported at least 3 episodes of digestive bleeding over the last 8 years, and was submitted to several sessions of endoscopic sclerotherapy of esophageal varices. At clinical examination, he was pale with a palpable liver and an enlarged spleen (Boyd III). Blood counts revealed reduction in all cell series: $3.2 \mathrm{x}$ $10^{6} \mathrm{red}$ cells $/ \mathrm{mm}^{3}$, hemoglobin $6.0 \mathrm{~g} / \mathrm{dL}, 1.4 \times 10^{3}$ white cells $/ \mathrm{mm}^{3}$, $51 \times 10^{3}$ platelets $/ \mathrm{mm}^{3}$. Blood chemistry and coagulation were unremarkable. There was no evidence of renal disease. Digestive endoscopy revealed small size distal esophageal varices and scars produced by previous sclerotherapy, erosive antral gastritis and hypertensive gastropathy. Serology for hepatitis B and Cgave negative results. There was no clinical, electrocardiographic or echocardiographic evidence of pulmonary hypertension. He was operated on ( splenectomy and esophagogastric devascularization) and a liver biopsy confirmed the diagnosis of Symmers' ibrosis.

\section{RESULTS}

Note in Figure 1 the patientwith hepatosplenomegaly, the aspect of a liver with advanced periportal fibrosis and the Ec pattern of WHO for ultrasound in schistosomiasis mansoni (advanced central e peripheral fibrosis + thickening of the gallbladder wall). US of the abdomen with a SIEMENS Sonoline Prima device showed enlarged periportal bands with increased echogenicity suggesting intense periportal fibrosis (Figure 2). Evidence of portal

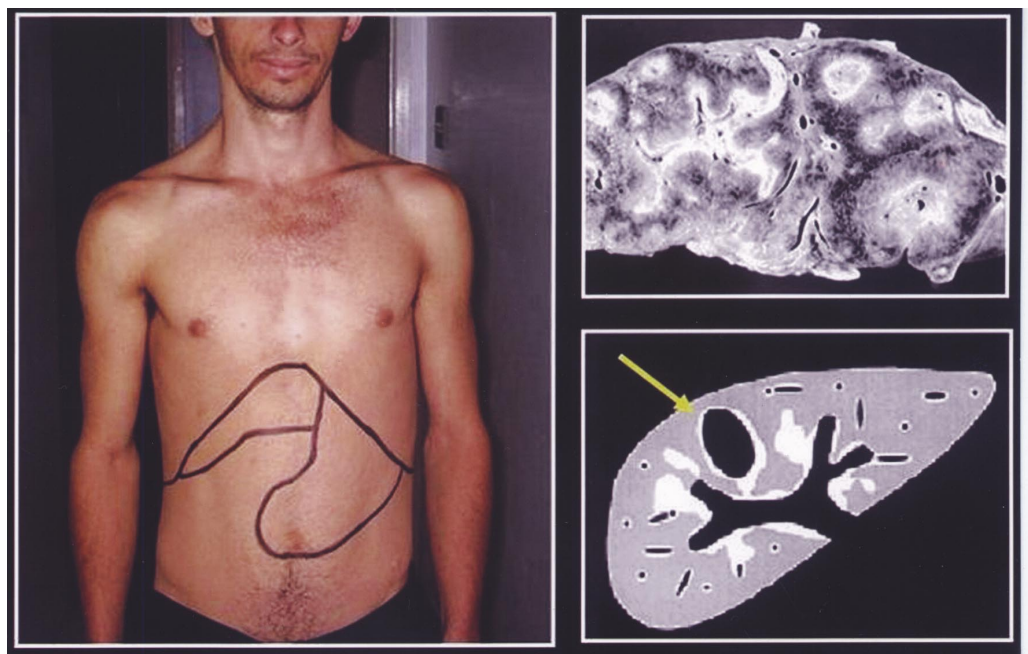

Figure 1 - The patient with hepatosplenomegaly. Note, on the right side, the periportal fibrosis in the liver of a patient who died with hepatosplenic schistosomiasis. Also on the right, below the liver there is a drawing of the Ec pattern of WHO for ultrasonography in schistosomiasis mansoni (advanced central and peripheral fibrosisand thickening of the gallbladder wall- yellow arrow).

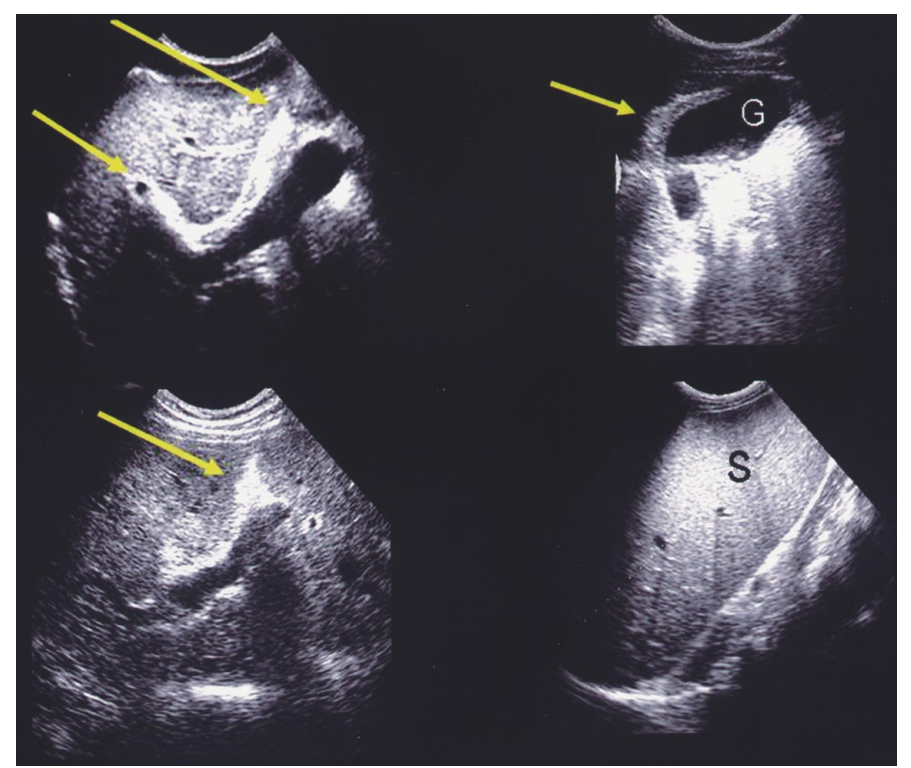

Figure 2 - Ultrasound of the patient showing periportal thickening (yellow arrows on the left side), thickening of the gallbladder wall ( $\mathrm{G}=$ gallbladder; yellow arrow $=$ thickened wall) and the enlarged spleen (S). 
hypertension, with portal vein and spleen enlargement and collateral veins, and thickening of the gallbladder wall were also noticed. MRI of the abdomen was performed using a Giroscan Intera superconducting 1.5 Tesla magnetic system (Philips Netherlands) (Figures 3, 4 and 5). The sequences demonstrated the broad periportal bands seen on liver ultrasound. On T1 sequences, these bands were hypointense to the liver, while they had increased signal on T2-weighted images. Thickening of the gallbladder wall, enlargement of spleen, splenic and portal veins and collateral vessels were detected. After contrastadministration, T1-weighted images revealed enhancement of the gallbladder wall and periportal space (Figure 6).

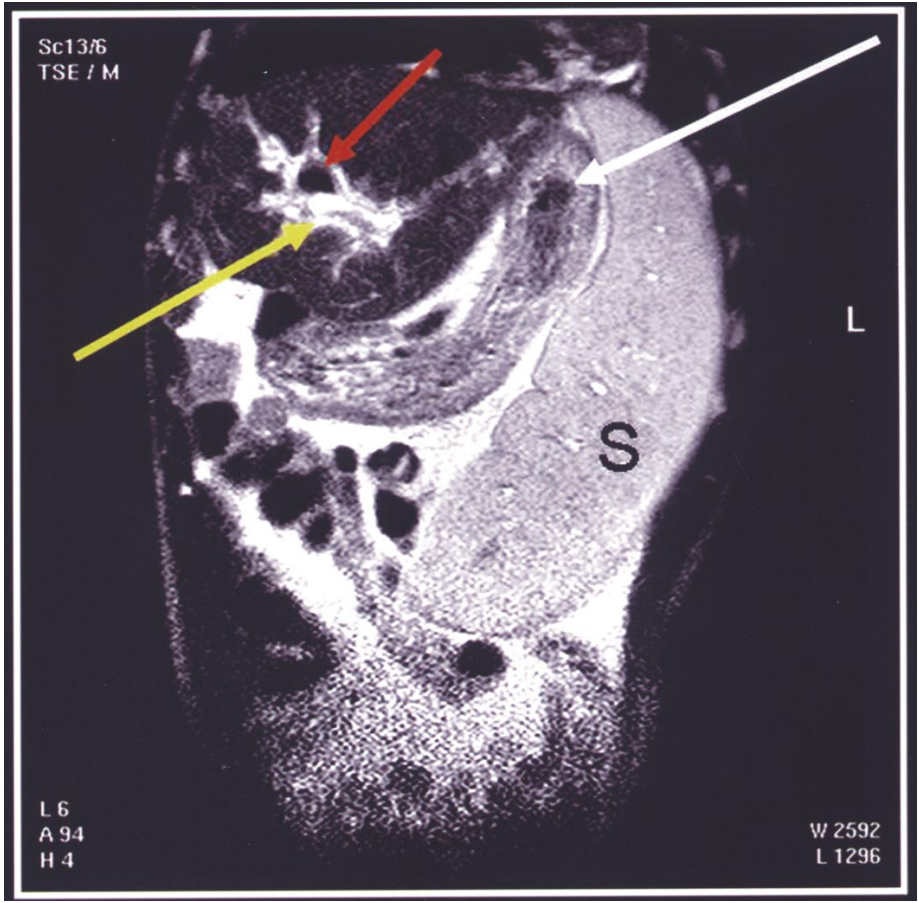

Figure 3 - MRI T2-weighted image of liver and spleen - a coronal section. Liver with periportal thickening (yellow arrow) around the portal vein (red arrow). There is a huge spleen $(\mathrm{S})$. White arrow = stomach

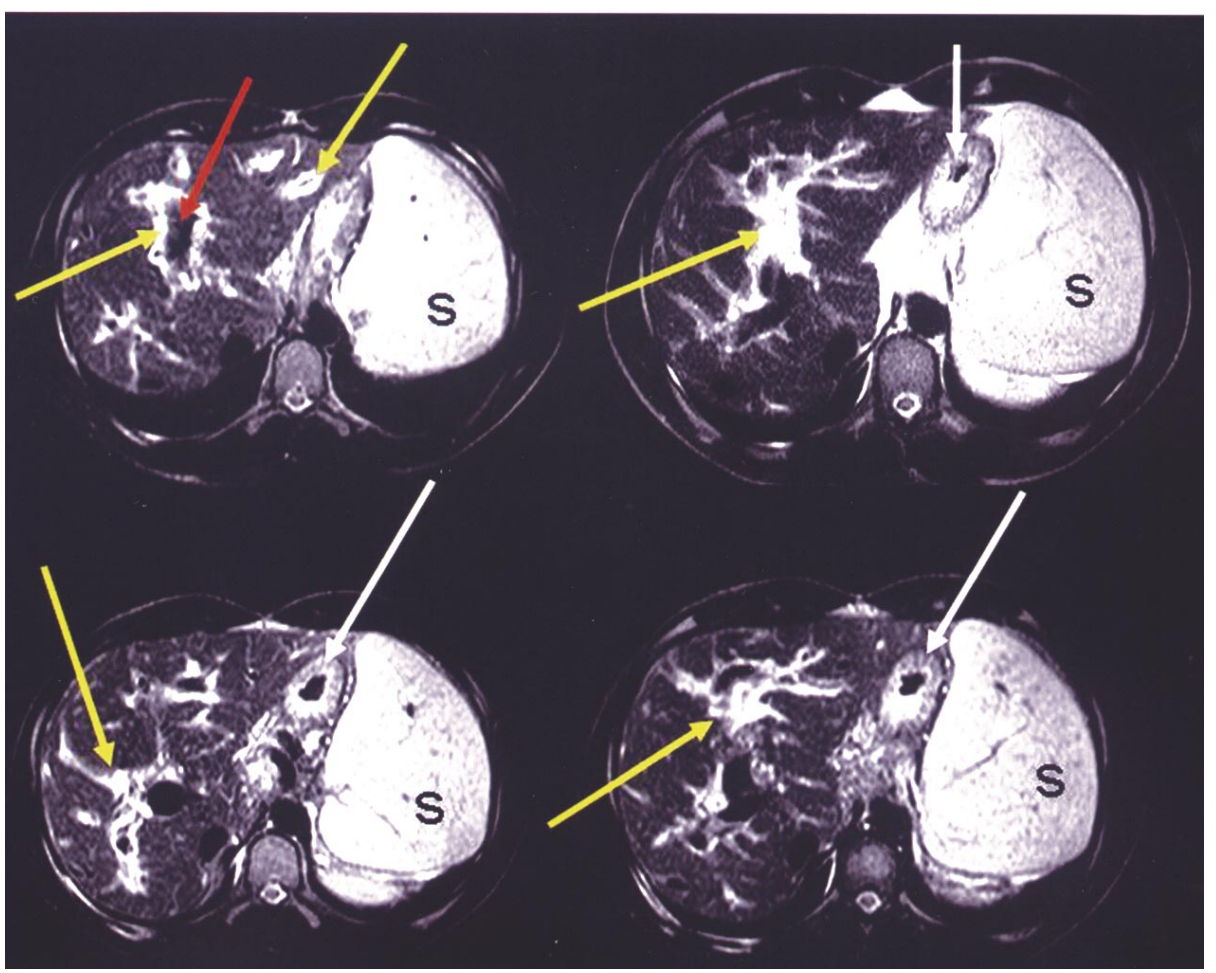

Figure4- MRI T2-weighted image of liver and spleen - transversal section. There are four images showingdifferent aspects of periportal fibrosis in the liver ( the vein in the center appears dark - red arrow). Periportal thickening (yellow arrows). White arrows = stomach; $\mathrm{S}=$ spleen. 


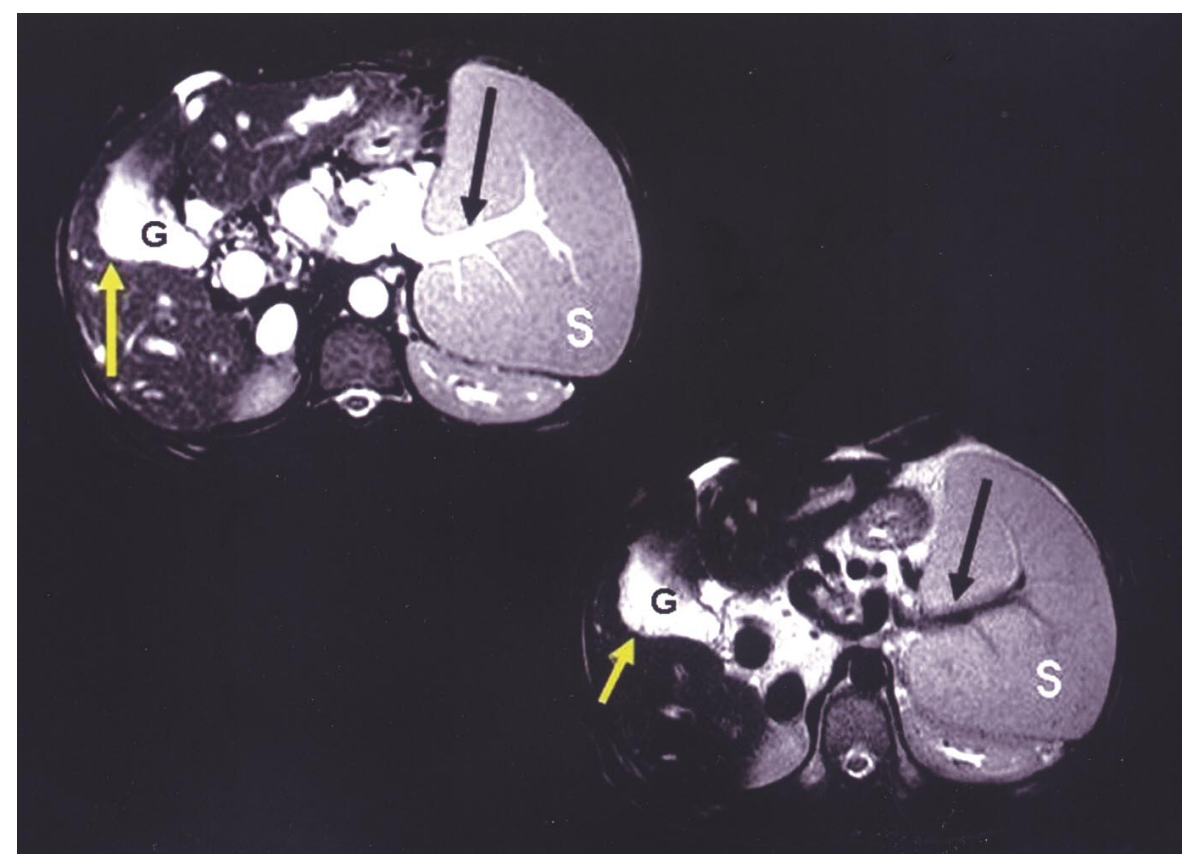

Figure 5 - MRI T2-weighted image of liver and spleen - transversal section. The vessels are easily identified. Black arrow = splenic vein; yellow arrow $=$ thickening around the gallbladder wall. $\mathrm{G}=$ gallbladder; $\mathrm{S}=$ spleen .

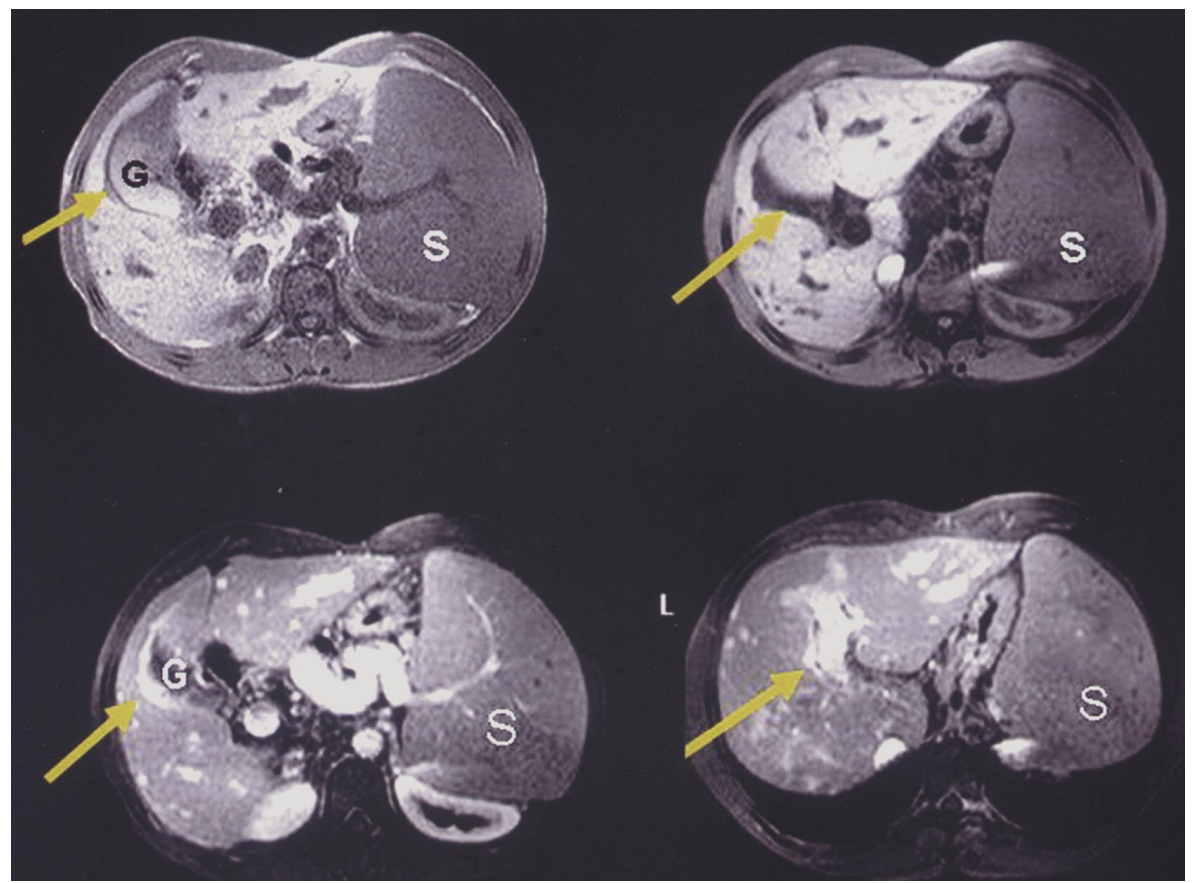

Figure 6 - MRI T1-weighted image of liver and spleen with fat suppression - transversal section. S= spleen; $\mathrm{G}=$ gallbladder. The white areas around the vessels (fibrosis) and gallbladder (fibrosis) - yellow arrows and also the blood inside the vessels, seen in previous images, became black/gray on the two upper figures. Note, in the two lower figures, that there is an enhancement of the gallbladder wall (yellow arrow) and of the periportal thickening (yellow arrow) after the intravenous infusion of contrast (gadolinium).

\section{DISCUSSION}

In the patient reported herein, the US and MRI were in accordance. However, MRI scans gave a more objective and familiar view of the intra-abdominal organs. It is easier to pinpoint the alterations caused by the disease in the walls of the gallbladder, the periportal thickening, and to identify the abdominal venous system.
Until veryrecently the diagnosis of hepatosplenic schistosomiasis was based on the evaluation of hepatosplenomegaly by abdominal palpation 7 . In the lasttwo decades, however, studies comparing spleen palpation to more accurate methods for the diagnosis of spleen enlargementhave shown the limitations of abdominal palpation ${ }^{3610}$. Intense periportal thickening and Symmers' fibrosis have been unveiled in patients without spleen enlargement both on autopsy 
and by US examination ${ }^{9,17}$. In addition, enlarged spleens were revealed by US examination in people with active schistosomiasis, living in endemic areas, concurrently with a normal liver appearance ${ }^{9}$. So, the definition of hepatosplenic schistosomiasis based on the finding of S. mansoni eggs in the stools of a person with liver and spleen enlargement is no longer appropriate.

These are examples of how new and more accurate techniques allow a more comprehensive view of schistosomal morbidity ${ }^{1119}$. MRI has been shown to be a very accurate imaging method in the evaluation of a variety of diseases. The most frequent findings reported in hepatosplenic schistosomiasis using MRI were accentuation of periportal signal in T2-weighted sequences, and hypointense signal in relation to the normal liver parenchyma in T1weighted sequences with fat suppression. T1-weighted sequences showed accentuation of periportal signal after contrast administration. It has been suggested that the hyperintense signal observed in T2-weighted sequences may differentiate periportal inflammation from fibrosis, what can not be achieved by US examination. It is also of greatinterest to know whether MR will be able to recognize patients with less advanced lesions of the liver in schistosomiasis mansoni and help to detect patients in the earlier phases of the disease - a well known limitation of ultrasonography.

The data presented above suggest that MRI findings are characteristic and diagnostic of hepatosplenic schistosomiasis and that it can be a more accurate method for the identification of morbidity, progression of the disease and possibly of involution of fibrosis atter treatment. MRI may come to be the gold standard procedure for the evaluation of periportal fibrosis and inflammation in schistosomiasis mansoni. Study of a large series of patients is under way.

\section{REFERENCES}

1. Amaral RS, Porto MAS. Evolução e situação atual do controle da esquistossomose no Brasil. Revista da Sociedade Brasileira de Medicina Tropical 27 ( supl III) : 73-90, 1994.

2. Barbosa MM, Lamounier JA, Oliveira EC, Souza MV, Marques DS, Silva AA, Lambertucci JR. Pulmonary hypertension in schistosomiasis mansoni. Transactions of the Royal Society of Tropical Medicine and Hygiene 90: 663-665, 1996.

3. Barkun NA, Camus M, Green L, Meagher T, Coupal L, De Stempel J, Grover AS. The bedside assessment of splenic enlargement. American Journal of Medicine 91: 512-518, 1991.

4. Barata CH, Pinto-Silva RA, Lambertucci JR. Abdominal ultrasound in acute schistosomiasis mansoni. British Journal of Radiology 72: 949-952, 1999.

5. Fataar S, Bassiony H, Satyanath S, Rudwan MA, Khaffaji S, el Magdy W, AlAnsari AG, Hanna R. CT of hepatic schistosomiasis mansoni. American Journal of Radiology 145: 63-66, 1985.
6. Gerspacher-Lara R, Pinto-Silva RA, Serufo JC, Rayes AAM, Drummond SC, Lambertucci JR. Spleen palpation for the evaluation of morbidity due to schistosomiasis mansoni. Memórias do Instituto Oswaldo Cruz 93: 67-71, 1998.

7. Kloetzel K. Splenomegaly in schistosomiasis mansoni. American Journal of Tropical Medicine 11: 472-476, 1962.

8. Lambertucci JR, Andrade LM, Pinto-Silva RA. Magnetic resonance imaging of the liver in hepatosplenic schistosomiasis mansoni. Revista da Sociedade Brasileira de Medicina Tropical 35: 679-680, 2002.

9. Lambertucci JR, Cota GF, Pinto-Silva RA, Serufo JC, Gerspacher-Lara R, Drummond SC, Antunes CM, Nobre V, Rayes AA. Hepatosplenic schistosomiasis mansoni in field-based studies: a combined clinical and sonographic definition. Memórias do Instituto Oswaldo Cruz 96: 147-150, 2001.

10. Lambertucci JR, Gerspacher-Lara R, Pinto-Silva RA, Barbosa MM, Teixeira R, Barbosa HF, Serufo JC, Rezende DF, Drummond SC, Rayes AAM. 0 projeto Queixadinha: a morbidade e o controle da esquistossomose em área endêmica no nordeste de Minas Gerais, Brasil. Revista da Sociedade Brasileira de Medicina Tropical 29: $127-135,1996$

11. Lambertucci JR, Serufo JC, Gerspacher-Lara R, Rayes AA, Teixeira R, Nobre V, Antunes CM. Schistosoma mansoni: assessment of morbidity before and after control. Acta Tropica 77: 101-109, 2000.

12. Mergo PJ, Ros PR. Imaging of diffuse liver disease. Radiological Clinics of North America 36: 365-475, 1998.

13. Niamey Working Group. Ultrasound in schistosomiasis. A practical guide to the standardized use of ultrasonography for the assessment of schistosomiasis-related morbidity. World Health Organization/TDR/SCH/ ULTRASON/document. Geneva, Switzerland, 2000.

14. Patel AS, Castillo DF, Hibbeln JF, Watkins JL. Magnetic resonance imaging appearance of hepatic schistosomiasis, with ultrasound and computed tomography correlation. American Journal of Gastroenterology 88: 113-116, 1993.

15. Petroianu A. Tratamento cirúrgico da hipertensão porta na esquistossomose mansoni. Revista da Sociedade Brasileira de Medicina Tropical 36: 253-265, 2003.

16. Pinto-Silva RA, Abrantes WL, Antunes CM, Lambertucci JR. Sonographic features of portal hypertension in schistosomiasis mansoni. Revista do Instituto de Medicina Tropical de São Paulo 36: 355-361, 1994.

17. Prata A, Andrade ZA. Fibrose hepática de Symmers sem esplenomegalia. 0 Hospital 63: 617-623, 1963.

18. Richter J, Domingues ALC, Barata CH, Prata AR, Lambertucci JR. Report on the second satellite symposium on ultrasound in schistosomiasis. Memórias do Instituto Oswaldo Cruz 96: 151-156, 2001.

19. Serufo JC, Antunes CM, Pinto-Silva RA, Gerspacher-Lara R, Rayes AA, Drummond SC, Reis CM, Martins MJ, Mingoti AS, Lambertucci JR. Chronic carriers of hepatitis B surface antigen in an endemic area for schistosomiasis mansoni in Brazil. Memórias do Instituto Oswaldo Cruz 93: 249-253, 1998.

20. Strauss E. Hepatitis C. Revista da Sociedade Brasileira de Medicina Tropical 34: 69-82, 2001.

21. Willemsen UF, Pfluger TH, Zoller WG, Kueffer G, Hahn K. MRI of hepatic schistosomiasis mansoni. Journal of Computed Assisted Tomography 19: 811-813, 1995. 